\title{
Inorganic Strategy Priority and The Company Valuation Analysis of Pt Bank Bni Syariah to Become Buku III Bank
}

\author{
Dio Ardana Pramandika, and Uke Marius Siahaan
}

\begin{abstract}
PT Bank BNI Syariah with a core capital of 4.4 trillion rupiahs, has a roadmap design to move up to BUKU III bank in 2020. One of the requirements to become a BUKU III bank is to have a core capital of 5 trillion rupiahs. With the current existing core capital, the company needs additional funding to meet those requirements. Inorganic Strategy is considered as the best option to add the company's core capital. Using the Analytical Hierarchy Process (AHP) method, the author calculates the best possible Inorganic Strategy alternatives for the company, resulting in Initial Public Offering as the best alternatives. Thus, the company valuation is calculated to determine the fair value of the company for IPO. The company equity posture after IPO will be PT. Bank Negara Indonesia, Tbk. (79,95\%), PT. BNI Life $(0,05 \%)$ and public $(\mathbf{2 0 , 0 0 \%})$. The company offered the share price at $\mathbf{R p}$ 800 per share. Total equity gained after the public offering will be $R p 2,001$ trillion, thus the new core capital of the company is Rp 6,4 trillion.
\end{abstract}

Index Terms - BNI Syariah, BUKU III Bank, core capital, Inorganic Strategy, AHP, company valuation, IPO, equity, share price.

\section{INTRODUCTION}

To develop its business, every company needs to be sustainable and profitable. One way to develop the business is by expansion or investment. Expansion can be done by using an organic strategy (internal funds) or inorganic strategy (external funds) options. Internal funds are obtained from the company's retained earnings while the external funds are obtained from the debt or share issuance. To finance the company investment, funding taken from the internal source is sometimes not sufficient. Therefore, it is a need for a company to find an external source of financing. PT Bank BNI Syariah with a core capital of 4.4 trillion rupiahs, has a roadmap design to move up to BUKU III bank in 2020. One of the requirements to become a BUKU III bank is to have core capital of 5 trillion rupiahs. With existing core capital, companies need additional funding to meet those needs.

\section{LITERATURE REVIEW}

\section{A. Industry Analysis}

External analysis is carried out to determine the external condition of the company, so the most suitable inorganic strategy can be applied based on the external condition that affected the company performance. The framework used in this internal analysis is Porter 5 Forces framework, with the results as follows:

\section{Threat of New Entrants (LOW)}

The threat of new entrants in Sharia Banking industry can be considered as low to medium. Low sharia banking literacy $(8 \%)$ and inclusion $(11 \%)$ in Indonesia and the low market share $(5.9 \%)$ between conventional and sharia bank will make this industry does not look interesting for new entrants. It also takes quite some upfront investment to start a sharia banking in Indonesia as Indonesia has a large area to cover.

\section{Bargaining Power of Suppliers (HIGH)}

Supplier in the banking industry can be considered as the third party fund. Because the market input for the banking industry is their funding. The bargaining power of the suppliers in sharia bank is high. When looking at the major inputs that sharia bank need, we see that they are really dependent on third party fund (giro, savings, deposit). These inputs are very much affected with external environment condition, such as political condition and economic growth. That factors are really fluctuated and also affected by global condition.

\section{Bargaining Power of Buyers (HIGH)}

The bargaining power of buyers also mentioned as the market outputs. In banking industry, the market output is the product that the bank provides. In sharia banking it includes savings product, consumer financing, commercial financing and bank services. Bargaining power of buyers in sharia bank is high. Customers are able to compare the advantage and disadvantage for each sharia bank through the website. There is no any significant switching cost to change between sharia banks. Therefore, brand loyalty from parent company seem to be very affect the brand loyalty for their subsidiary sharia banks.

\section{Threat of Substitute (HIGH)}

The alternative product which has the same function as sharia banking can be considered as the substitute for sharia banks. Conventional bank and other financial institutions that serve as money collector and creditor are the alternative 
substitute product for sharia banks. The biggest threat is the conventional banks, because they are already mature and have better technology and services than sharia bank.

\section{Rivalry among Existing Competitor (MEDIUM)}

When looking at the sharia bank industry in Indonesia, we can see that the main focus for this industry is to educate Indonesian citizen to choose sharia banking than conventional banking. With the biggest number of Muslim in the world, the low market share and low sharia literacy reflected that there are many Muslims who have not believe in sharia banking. It means that there are plenty of room for each sharia bank to grow. So, the rivalry between each sharia bank will not be really high.

\section{B. Company Analysis}

The company can be summarized into SWOT framework. The internal review explained in Strengths and Weakness, while the external review explained in Opportunity and Threat, with the results as follows:

TABLE I: Swot Analysis of BNI SYARIAH

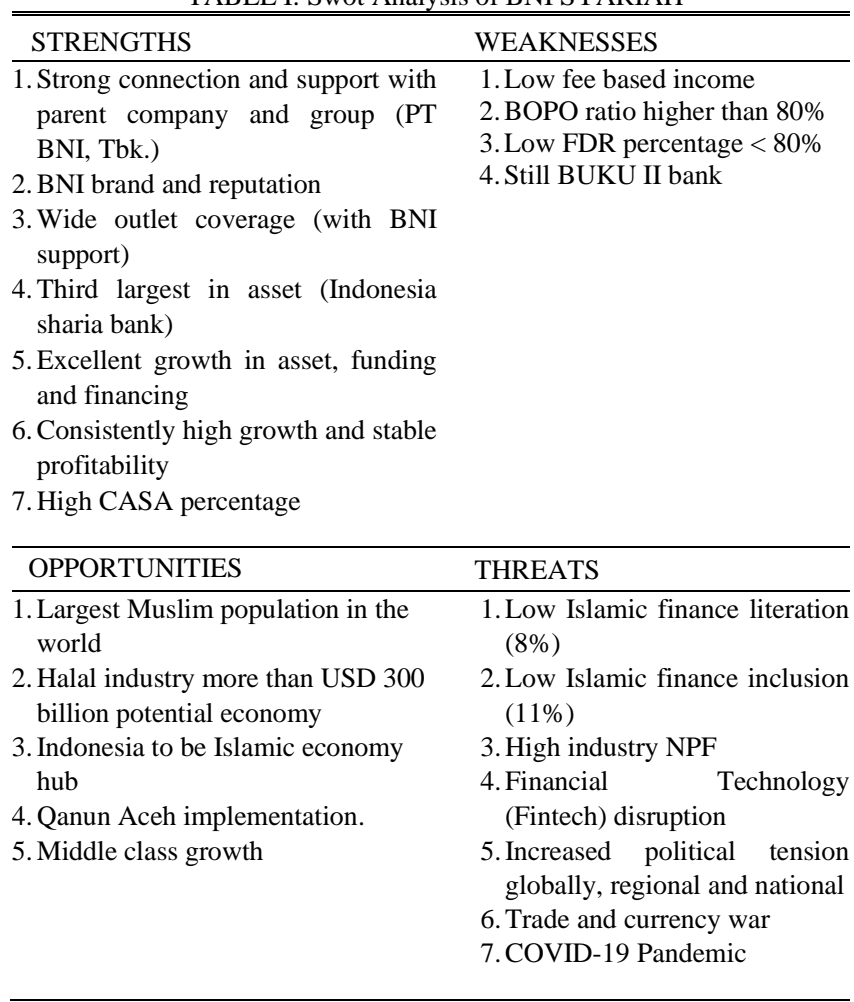

\section{METHODOLOGY}

\section{A. Type and Source of Data}

The data collection method used in this study is a library study. Library research to complete and supplement the primary data obtained and enrich the writing materials. Data to be obtained and processed are as follows:

- Primary data that obtained directly from research objects such as annual reports, company profiles and prospectus.

- Secondary data that obtained from other sources such as Central Bureau of Statistics, Bank Indonesia, the Indonesia Stock Exchange, Financial Service Authority, the International Monetary fund and other media.

\section{B. Data Period}

The data period used in this research is from 2015 to 2019 which can be accessed in PT Bank BNI Syariah Strategic Planning Division during the research, and also available at BNI Syariah website.

\section{Data Processing Methods}

The analytical method used to assess the company fair value in this research is a top-down fundamental analysis approach. The stage of the analysis are starting from the macroeconomic conditions, industry conditions and microanalysis of the company both qualitatively and quantitatively.

Literature on the macroeconomics, Sharia banking industry and the internal conditions of the company is used as data that is created to meet the requirements for analysing the state of the company and is also used as data input in the valuation process. Data are applied to estimate the fair value of a company using a discounted cash flow (DCF) approach. The evaluation is based on the method described in Damodaran [2].

\section{Findings And ARgument}

\section{A. Inorganic Strategy Analysis}

Inorganic Strategy Analysis was made by determining the goals (priority) and calculate the matrix score of the alternatives and the criteria.

Alternatives is the option that the company needs to do to achieve the main goal. For this research, there are four options of alternatives to be proposed:

1. Initial Public Offering (IPO).

2. Strategic Partnership (SP).

3. Capital Injection (CI).

4. Merger and Acquisition (MnA).

The definition of criteria in AHP is the relating factor that affected the value of each alternatives in decision making process. The calculation of their weight is central in this method to assess the alternatives. In this research, the author defined six criteria, which are time, cost, risk, management effort, management authority and market exposure.
1. Time
4. Management Effort
2. Cost.
5. Management Authority
3. Risk

\section{Market Exposure}

Fig. 1. Priority Vector Tree.

Analytical Hierarchy Process method shows that the most suitable inorganic strategy for PT Bank BNI Syariah is Initial Public Offering with 0,348 point, above all of the 
other alternatives (Capital Injection 0,337; Merger and Acquisition 0,153; and Strategic Partnership 0,161).

Synthesis with respect to: Goal: INORGANIC STRATEGY PRIORITY

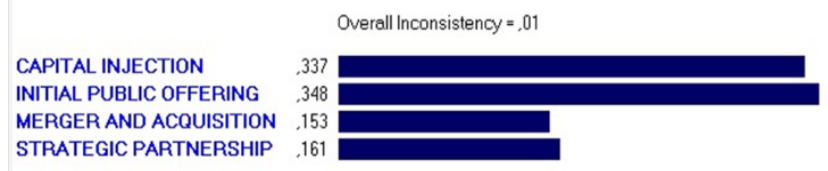

Fig. 2. Final results of Inorganic Strategy Priority with AHP.

\section{B. Company Valuation Analysis}

The Inorganic Strategy Analysis resulted Initial Public Offering as the company inorganic strategy alternatives to add their core capital. Based on the research's objectives, then the next step is to determine the valuation of the company for Initial Public Offering.

In this research, the author decided to use the Excess Return Model approach to calculate the valuation of the company. Excess Return Models Valuation is a valuation method when in this such a model, the value of a firm can be written as the sum of capital invested currently in the firm and the present value of dollar excess returns that the firm expects to make in the future [2].

\section{Project Period}

In this paper, the source of data is from the company's Annual Financial Statement from 2015-2019. The author decided to set the projection period for 5 years, due to the level of uncertainty in banking industry that really depends on global macro economy and heavily regulated. Therefore, the projection period will be from 2020-2024.

\section{Return on Equity Estimation}

The author assumes that the return on equity over the next 5 years will increase at average $15 \%$ from current year average $11,8 \%$, reflecting the strong performance of the company and the prospecting growth of sharia industry in Indonesia. The company also still in the growth stage, so the $15 \%$ average ROE growth over next 5 years will be feasible.

\section{Cost of Equity}

The cost of equity calculation in this research use capital asset pricing model (CAPM) method.

\begin{tabular}{|lll|}
\hline Variable & Value & Source \\
\hline Risk Free Rate & $7,37 \%$ & 10 Y Government Bond (June \\
& & $2020)$ \\
Beta & 1,23 & Industry Average \\
Market Premium $(R m-R f)$ & $3,48 \%$ & Aswath Damodaran (April 2020) \\
\hline Cost of Equity & $11,5 \%$ & $\mathbf{K} e=R f+\beta(R m-R f)$ \\
\hline
\end{tabular}

Fig. 3. Calculation of Cost of Equity.

\section{Excess Return Model Calculation and Terminal Value}

For calculating the excess return model, there are some variable needed as the input. The inputs are Initial Net Income, Book Value of Equity and Dividend Payout Ratio.

The initial income is Net Income in year $2019 \mathrm{Rp}$ 603.153 million. The Book Value of Equity is total equity in year 2019 Rp 4.735.076 million. For Dividend Payout Ratio, although there was no dividend issuing in the past years, but after IPO the author estimated the DPR will be at $25 \%$, following the parent company historical DPR.

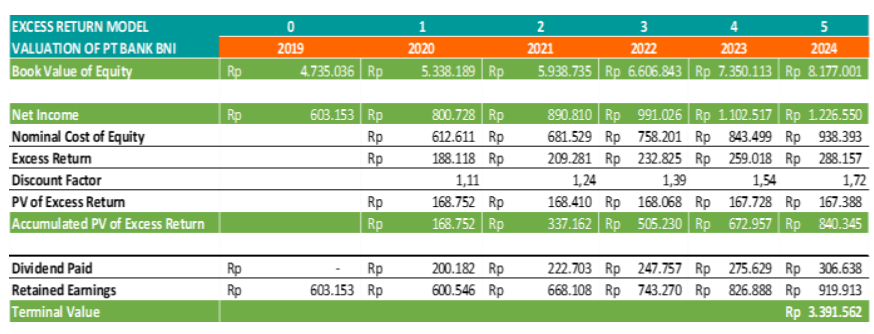

Fig. 4. Return Excess Model calculation.

After 5 years, the expected accumulated present value of excess return from the company is Rp 840.345 million and the Terminal Value is $\operatorname{Rp} 3.391 .562$ million.

\section{Total Value}

The total value of the company is obtained by summing the present value of accumulated excess return and the present value of terminal value.

Total value $=$ Beginning $\mathrm{BV}+\mathrm{PV}$ of Accumulated Excess Return + PV of Terminal Value

$$
\begin{aligned}
& =4.735 .036+840.345+3.391 .562 \\
& =\operatorname{Rp} 8.966 .983 \text { million }(\operatorname{Rp} 8,9 \text { trillion })
\end{aligned}
$$

\section{Number of Shares}

For IPO preparation, the company need to conduct a stock split action so the share price will be affordable for the public. The stock split scheme showed in table below:

\begin{tabular}{|l|r|}
\hline Current Company Value & Rp \\
\hline Firm Value & 8.966 .982 .942 .474 \\
Current Share Outstanding & 2.501 .500 \\
Split Share Outstanding (1:4000) & 10.006 .000 .000 \\
\hline Value per Share & Rp $\quad 896$
\end{tabular}

Fig. 5. Stock split scheme and new share price.

The share outstanding will be split by $1: 4000$, so the total new share outstanding is 10.006 .000 .000 shares. With the company valuation based on excess return model of $\mathrm{Rp}$ 8.966.982.942.474, the price per share will be Rp 896,12.

\section{Share Price for IPO}

The strategic planning from the company regarding the Initial Public Offering is the new share issued will be $20 \%$ from the total shares and the price per share will be offered with $10 \%$ discount from the value per share to attract more public investors. Thus, the new shares issued will be 2.501.500.000 shares at a price Rp 800 per share (0,9 PBV). The total equity gained from this IPO will be Rp 2.001.200 million.

\begin{tabular}{l|rr}
\hline IPO & & \\
Share Issued & & 2.501 .500 .000 \\
IPO Price & Rp & 800 \\
\hline Total Proceed & Rp & 2.001 .200 .000 .000 \\
\hline
\end{tabular}

Fig. 6. Initial Public Offering price and total proceed.

\section{Shareholder Structure}

After IPO, PT Bank Nasional Indonesia is still the major shareholders, but the percentage is diluted into 79,95\%. Public as the new shareholders will have $20 \%$ percentage of ownership in PT Bank BNI Syariah. The new shareholders posture after IPO showed in the table below. 


\begin{tabular}{|c|c|c|}
\hline New Shareholders Posture & Percentage & Shares \\
\hline PT Bank Nasional Indonesia, Tbk & $79,95 \%$ & 10.000 .000 .000 \\
\hline PT BNI Life Insurance & $0,05 \%$ & 6.000 .000 \\
\hline Public & $20,00 \%$ & 2.501 .500 .000 \\
\hline Total & $100,00 \%$ & 12.507 .500 .000 \\
\hline
\end{tabular}

Fig. 7. PT Bank BNI Syariah new shareholders posture after IPO.

\section{CONCLUSION AND RECOMMENDATION}

\section{A. Conclusion}

Based on the results of the analysis, this study concludes these following findings:

1. The results from Analytical Hierarchy Process method shows that the most suitable inorganic strategy for PT Bank BNI Syariah is Initial Public Offering with 0,348 point, above all of the other alternatives (Capital Injection 0,337; Merger and Acquisition 0,153; and Strategic Partnership $0,161)$

2. The results of the company valuation using Excess Return Valuation Model obtained the present value of the company is $\operatorname{Rp} 8.966 .983$ million or $\operatorname{Rp~8,9~trillion.~With~the~}$ number of outstanding shares after 1:4000 stock split is 10.006.000.000 shares, so the initial price per share of the company is Rp 896.

3. The company conduct an IPO with $20 \%$ new shares issued and offered at 1,3 PBV. Thus, the shares issued is 2.501.500.000 shares with the price per share $\mathrm{Rp} \mathrm{800.} \mathrm{The}$ total IPO proceed is $\mathrm{Rp} 2.001 .200 .000 .000$ or $\mathrm{Rp} 2,001$ trillion.

4. The new shareholders posture of PT Bank BNI Syariah will be PT BNI Tbk with 79,95\% shares, PT BNI Life with $0,05 \%$ shares and public with $20 \%$ shares.

\section{B. Recommendation}

Based on the results of research conducted, there are several recommendations that can be drawn and can be developed into the implementation plan, namely:

1. PT.Bank BNI Syariah must develop a fair market equity estimate derived from this study that reflects the company's performance as a reference in determining share prices for IPO purposes. Undervalued price will be resulted in the potential loss of the company so that funds obtained from the Initial Public Offering cannot be maximized.

2. Future investors will also use the value of fair market shares as a basis in making investment decisions to avoid paying prices above their fair market value and benefit them.

3. Common people and academics can make this research as a means of adding insight and reference in the field of Corporate Decision Making and Financial Service Firms Valuation.

4. The company should try to control its net income from fluctuating and declining which will generate negative perceptions from investors. The company also required to show activities that can increase the image or positive value for companies such as improving professionalism and applying the principles of good corporate governance in running its business activities.

\section{REFERENCES}

[1] Annual Report. (2015-2019). PT Bank BNI Syariah

[2] Damodaran, A. (2012). Investment valuation: Tools and Techniques for Determining the Value of any Asset. New Jersey: John Wiley \& Sons.

[3] Gitman, L. a. (2015). Principles of Managerial Finance 14th ed. Boston: Pearson.

[4] Hitt, Michael A. et al. (2010). Strategic Management: Competitiveness and Globalization.

[5] Humphrey, Albert. (2005). SWOT Analysis for Management Consulting. SRI Alumni Newsletter.

[6] Oguztimur, Senay. (2019). Why Fuzzy Analytic Hierarchy Process Approach for Transport Problems? Beşiktaş/İstanbul - Turkey: Yıldız Technical University Department of City and Regional Planning

[7] Porter, M. E. (1989). How Competitive Force Shape Strategy. In M. E. Porter, Readings in Strategic Management (pp. 133-143). London: Palgrave.

[8] Saaty, T. L., \& Peniwati, K. (2008). Group Decision Making: Drawing Out and Reconciling Difference. Pittsburgh: RWS Publications.

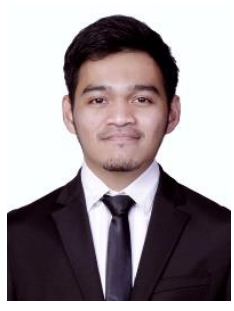

Dio Ardana Pramandika was born in Balikpapan, $4^{\text {th }}$ of April 1994. He earned his bachelor's degree in Geological Engineering from Padjajaran University. $\mathrm{He}$ is currently pursuing his master's degree in Business Administration from Institut Teknologi Bandung majoring in Business Risk and Finance.

He has work experience as an employee at Hitachi Chemicals in 2016 as a Business Development. Also, in 2019 at PT. Bank BNI Syariah as a Jr. Economist intern.

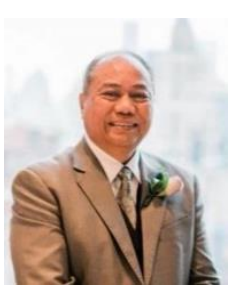

Uke Marius Siahaan is currently a lecturer at the School of Business and Management Institute of Technology Bandung (SBM ITB). He graduated from ITB Industrial Engineering in 1978, he obtained his first MBA in Marketing Strategy at the LPPM Business School, and continued with the Post Graduate Program with the Concentration in Finance and Banking at the Harvard Business School, Boston, Mass, USA Business School and was completed in the month of October 1987. He obtained his doctorate in the field of Financial Management from Brawijaya University in 2013.

His career began with working at the Raja Garuda Mas Group, build a Plywood Factory in Besitang, North Sumatra, then entering the world of banking, capital market and Merchant Banking with worked for JP Morgan in New York City, USA, and upon his return to Indonesia he continued by establishing 3 (three) Multi Finance units. 